\title{
Efektivitas Pemanfaatan Limbah Tahu Cair Melalui Metode Frekuensi Waktu Penyiraman terhadap Pertumbuhan Produksi Rumput Gajah (Pennisetum purpureum)
}

Maria M. M. Mau ${ }^{\mathrm{a}}$, Oktovianus R. Nahak, T.B ${ }^{\mathrm{b}}$ dan Kristoforus W. Kia ${ }^{\mathrm{c}}$

${ }^{a}$ Fakultas Pertanian, Universitas Timor, Kefamenanu, TTU - NTT, Indonesia, email: mariamelianamau@ gmail.com

${ }^{b}$ Fakultas Pertanian, Universitas Timor, Kefamenanu, TTU - NTT, Indonesia, email: oktovianusrafael@yahoo.co.id

${ }^{c}$ Fakultas Pertanian, Universitas Timor, Kefamenanu, TTU - NTT, Indonesia, email: willyamkia10@ gmail.com

\section{Article Info}

\section{Article history:}

Received 13 Desember 2019

Received in revised form 29 Desember 2019 Accepted 13 Januari 2020

https://doi.org/10.32938/ja.v5i1.920

\section{Keywords:}

Limbah tahu cair

Rumput gajah

Frekuensi penyiraman

\begin{abstract}
Abstrak
Penelitian ini dilaksanakan di kebun percobaan Fakultas Pertanian, Universitas Timor, Kelurahan Sasi, Kecamatan Kota, Kabupaten Timo Tengah Utara. Penelitian berlangsung selama 1 periode produksi (45 HST) yaitu dari akhir Maret sampai awal juni 2019. Tujuan dari penelitian ini untuk menganalisis nilai pertumbuhan dan produksi rumput gajah yang diberi perlakuan frekuensi waktu penyiraman limbah tahu cair. Penelitian ini merupakan penelitian eksperimen menggunakan Rancangan Acak Lengkap (RAL) yang terdiri dari 4 perlakuan dan 4 ulangan sehingga terdapat 16 unit satuan percobaan. Perlakuan yang diuji terdiri dari: $\mathrm{R}_{0}=$ Tanpa penyiraman limbah tahu, $R_{1}=$ Frekuensi penyiraman 2 hari sekali, $R_{2}=$ Frekuensi penyiraman 4 hari sekali, $R_{3}=$ Frekuensi penyiraman 6 hari sekali. Variabel yang diamati dalam penelitian ini adalah tinggi tanaman, diameter batang, berat segar daun dan berat kering daun. Hasil penelitian menunjukkan bahwa pemberian perlakuan frekuensi waktu penyiraman limbah tahu cair, memberikan pengaruh yang nyata terhadap berat segar daun yang di hasilkan namun tidak berbeda terhadap tinggi tanaman diameter batang dan berat kering yang dihasilkan. Disimpulkan bahwa limbah tahu cair dengan frekuensi waktu penyiraman yang baik terdapat pada perlakuan $\mathrm{R}_{1}$ yaitu 2 hari sekali, limbah tahu cair memiliki kemampuan untuk memperbaiki tekstur tanah dan dapat merangsang pertumbuhan rumput gajah dalam hal ini pertumbuhan tinggi tanaman, diameter batang, berat segar daun, dan berat kering daun.
\end{abstract}

\section{Pendahuluan}

Kebutuhan pakan ternak yang berkecukupan baik dari aspek kualitas maupun kuantitasnya merupakan sarana dalam rangka peningkatan produksi ternak ruminansia besar dan kecil. Pakan ternak ruminansia bersumber dari jenis hijauan baik jenis rumput maupun legum. Rumput merupakan pakan dasar ternak yang dibutuhkan dalam jumlah besar sehingga keberadaannya esensial bagi ternak ruminansia. Rumput Gajah (Pennisetum purpureum) adalah jenis rumpu potong unggul yang saat ini banyak dikembangkan oleh masyarakat peternak karena memiliki sifat sangat adaptif pada lingkungan kering selain itu memiliki produksi tinggi, palatable dan mengandung nutrisi yang sangat baik jika dibandingkan rumput lapangan. Sanderson dan Paul (2008) menyatakan bahwa rumput gajah, disukai oleh ternak ruminansia, tanaman ini dapat tumbuh didaerah yang nutrisi tanahnya rendah, sehingga tanaman ini dapat memperbaik kondisi tanah yang rusak akibat erosi. Tanaman ini juga dapat hidup pada tanah kritis dimana tanaman lain relatif tidak dapat tumbuh dengan baik, dan memilik kandungan nutrisi protein kasar 13-14\%, serat kasar 30-32\% (Suyitman, 2003).

Pengembangan produksi pakan ternak dapat diupayakan melalui pemberiaan bahan yang dapat memperbaiki sifat fisik dan kima tanah. Salah satu bahan organik yang dapat dimanfaatkan adalah buangan dari proses pembuatan tahu. Limbah tahu adalah limbah yang berasal dari sisa pengolahan kedelai yang terbuang dan tidak bisa dikonsumsi limbah tahu terdiri atas dua jenis yaitu limbah padat dan limbah cair (Yudhistira et al., 2016). Limbah padat dihasilkan dar proses penyaringan dan penggumpulan. Limbah ini sebagian besar diolah menjadi tempe gembus, pakan ternak dan tepung ampas tahu sebagai bahan baku pembuatan roti kering. sedangkan limbah cair dihasilkan dari proses perendaman, pencucian kedelai, penyaringan, pengempresan dan pancetakan tahu (Bahri, 2006). Limbah cair tahu merupakan hasil sampingan dari industri tahu yang saat ini belum banyak dimanfaatkan. Sampai saat ini limbah cair tahu juga menjadi masalah bagi masyarakat karena polusi udara yang ditimbulkan. Limbah tahu cair kaya akan kandungan protein yang mampu memberikan sumbangan nitrogen $(\mathrm{N})$ bagi tanaman. Nitrogen $(\mathrm{N})$ merupakan unsur hara yang dibutuhkan tanaman untuk pembentukan protein didalam sel-sel vegetati tanaman. Pemberian unsur nitrogen pada tanaman akan menyebabkan pertumbuhan vegetatif menjadi lebih baik dan warna daun menjadi hijau lebih tua (Fahmi et al., 2010)

Potensi limbah tahu cair untuk digunakan sebagai pupuk cair organik sangat menjanjikan mengingat kandungan limbah tahu cair memiliki kandungan nutrisi yang cukup tinggi sehingga dapat dimanfaatkansebagai pupuk cair Pemupukan sering didefinisikan sebagai menambah suatu bahan ke dalam tanah sehingga dapat menambah hara, merubah keadaan fisik, dan biologi tanah. Kasno (2009) dalam Winarni et al., (2013) menyatakan bahwa tanaman yang kekurangan unsur $\mathrm{N}$ akan mengalami pertumbuhan lambat, kerdil, daun hijau menjadi kekuningan, daunnya sempit, daun-daun tua menjadi cepat menguning dan mati. Tujuan dari penelitian ini untuk menganalisis pertumbuhan dan produksi rumput gajah yang diberi perlakuan frekuensi waktu penyiraman limbah tahu cair.

\section{Metode}

\subsection{Waktu dan Lokasi Penelitian}

Penelitian ini dilaksanakan pada kebun percobaan Fakultas Pertanian, Universitas Timor, Kelurahan Sasi, Kecamatan Kota Kefamenanu, Kabupaten Timor Tengah Utara. Penelitian berlangsung selama 1 periode produksi (45 HST) yaitu dari awal Maret-Juni 2019

\subsection{Materi Penelitian \\ Alat dan Bahan}

Peralatan yang digunakan terdiri dari alat ukur seperti; meteran, dan peralatan pendukung yaitu alat bercocok tanam seperti; pacul, parang, ember dan gembor, stek rumput gajah dan limbah tahu berbentuk cair yang diperoleh dari pabrik pembuatan tahu serta lahan pertanian yang digunakan seluas $50 \mathrm{~m}^{2}$.

\subsection{Rancangan Penelitian}

Penelitian ini merupakan penelitian eksperimen dengan menggunakan Rancangan Acak Lengkap (RAL) yang terdiri dari 4 perlakuan dan 4 ulangan, yang terdiri dari :

$\mathrm{R}_{0}=$ Tanpa penyiraman limbah tahu

$\mathrm{R}_{1}=$ Frekuensi penyiraman 2 hari sekali

$\mathrm{R}_{2}=$ Frekuensi penyiraman 4 hari sekali

$\mathrm{R}_{3}=$ Frekuensi penyiraman 6 hari sekali

\subsection{Prosedur Penelitian}

\subsubsection{Persiapan Lahan}

Lahan yang digunakan diolah dalam bentuk bedeng dimana tiap bedeng dibuat dengan ukuran 1x2 meter sebanyak 16 bedeng, jarak antara bedeng $30 \mathrm{~cm}$ dan jarak antara blok $50 \mathrm{~cm}$. Tinggi bedeng dibuat dengan ukuran $20 \mathrm{~cm}$

\subsubsection{Penanaman dan pemeliharaan}

Penanaman rumput gajah menggunakan stek yang telah dipotong dengan ukuran seragam yaitu $\pm 30 \mathrm{~cm}$. Sebelumnya dilakukan pembuatan lubang tanam dengan kedalaman $15 \mathrm{~cm}$ dan jarak antara lubang tanam $40 \mathrm{~cm}$ sehingga pada tiap bedeng terdapat 15 lubang tanam dan tiap lubang tanam ditanam sebanyak 2 stek rumput gajah. Setelah ditanam selanjutnya disiram menggunakan air sebanyak 2 liter pada tiap lubang tanam lalu dibiarkan selama 10 hari sebelum diberi perlakuan. Pembersihan gulma dilakukan dengan mencabut jenis tanaman lain yang hidup pada bedeng dan sekitar lahan penelitian

\subsubsection{Pemberian perlakuan}

Pemberian perlakuan berupa penyiraman limbah tahu cair dilakukan sesuai perlakuan dan hasil pengacakan pada tiap bedeng. Pemberian limbah tahu cair diberikan pada waktu 11 HST (hari setelah tanam) dimana tiap penyiraman diberikan sebanyak 10 liter limbah tahu cair pada tiap bedeng.

\subsubsection{Pengambilan data}

Pengambilan data tinggi tanaman, diameter batang diambil tiap minggu sekali sedangkan data berat segar dan berat kering tanaman diambil pada akhir masa penelitian.

\subsection{Variabel Penelitian}

\subsubsection{Tinggi Tanaman (TTn)}

Tinggi tanaman di ukur setelah 14 hari setelah tanam dan di ulang setiap 7 hari sampai tanaman mencapai pertumbuhan vegetatif maksimum. Penggukuran tinggi tanaman di lakukan dari permukaan tanah sampai bagian ujung batang menggunakan mister $(\mathrm{cm})$.

$\mathrm{TT}=\mathrm{TT}_{1}+\mathrm{Tt}_{2}+\mathrm{TT}_{3}+\mathrm{TT}_{4}$

Keterangan :

TT = Tinggi Tanaman

$\mathrm{TT}_{1}=$ Tinggi Tanaman pengukuran pertama

$\mathrm{TT}_{2}=$ Tinggi Tanaman pengukuran kedua

$\mathrm{TT}_{3}=$ Tinggi Tanaman pengukuran ketiga

$\mathrm{TT}_{4}=$ Tinggi Tanaman pengukuran keempat

$\mathrm{T}=$ Waktu (Minggu) 


\subsubsection{Diameter Batang (DBt)}

Diameter batang di ukur pada saat 14 hari setelah tanam di ulang setiap 7 hari sampai tanaman mencapai pertumbuhan vegatatif maksimum. Alat yang di gunakan untuk mengukur diameter batang adalah jangka sorong.

$\mathrm{DB}=\mathrm{DB}_{1}+\mathrm{DB}_{2}+\mathrm{DB}_{3}+\mathrm{DB}_{4}$

$$
\mathrm{T}
$$

Keterangan :

DB = Diameter Batang

$\mathrm{DB}_{1}=$ Diameter Batang pengukuran pertama

$\mathrm{DB}_{2}=$ Diameter Batang pengukuran kedua

$\mathrm{DB}_{3}=$ Diameter Batang pengukuran ketiga

$\mathrm{DB}_{4}=$ Diameter Batang pengukuran keempat

$\mathrm{T}=$ Waktu (Minggu)

\subsubsection{Berat Segar Daun (BSD)}

Setelah tanaman berumur 45 hari, daun rumput gajah di dipanen kemudian ditimbang. Data hasil penimbangan merupakan data berat segar daun.

2.5.4 Berat Kering Daun (BKD)

Daun rumput gajah yang sudah dikeringkan menggunakan matahari selama 1 hari selanjutnya dikeringkan menggunakan oven pada suhu $70^{\circ} \mathrm{C}$ selama 2 hari Selanjutnya ditimbang. Data hasil penimbangan dicatat sebagai data berat kering daun.

\subsection{Analisis Data}

Data yang di peroleh dianalisis menggunakan analisis sidik ragam (Anova) sesuai dengan rancangan yang di gunakan yaitu Rancangan Acak Lengkap (RAL). Analisis data menggunakan Sofware SAS Versi 9.1

\section{Hasil dan Pembahasan}

\subsection{Tinggi Tanaman}

Tinggi tanaman merupakan salah satu kriteria yang digunakan dalam mengukur lajupertumbuhan tanaman. Data hasil pengamatan dapat dilihat pada Gambar 1.

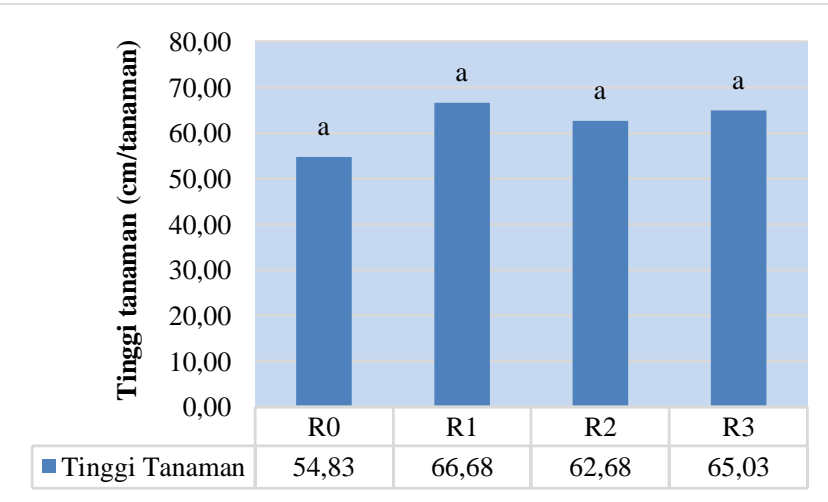

Gambar 1. Rataan Pertumbuhan Tinggi Tanaman (cm/tanaman)

Data pada Gambar 1 menunjukkan bahwa tinggi tanaman rumput gajah yang diberi perlakuan frekuensi penyiraman limbah tahu 2 hari sekali $\left(R_{1}\right)$ menghasilkan tinggi tanaman terbaik sebesar 66,68 cm/tanaman, diikuti perlakuan frekuensi penyiraman 6 hari sekali $\left(\mathrm{R}_{3}\right)$ dengan tinggi tanaman 65,03 $\mathrm{cm} /$ tanaman, frekuensi penyiraman 4 hari sekali $\left(\mathrm{R}_{2}\right)$ dengan tinggi 62,68 $\mathrm{cm} /$ tanaman, sedangkan yang terendah adalah pada tanaman dengan perlakuan kontrol (tanpa penyiraman limbah tahu) dengan tinggi 54,83 cm/tanaman.

Hasil analisis sidik ragam (Anova) menunjukkan bahwa pemberian perlakuan frekuensi penyiraman limbah tahu pada rumput gajah berpengaruh tidak nyata terhadap tinggi tanaman yang dihasilkan. Kuat dugaan bahwa pada frekeunsi penyiraman sampai dengan 6 hari sekali $\left(R_{3}\right)$ masih mampu menyediakan hara yang cukup untuk digunakan tanaman dalam menyuplai kebutuhan untuk pertumbuhan tinggi tanaman. Pernyataan Farida (2009) bahwa limbah tahu cair mengandung bahan organik, kandungan unsur kimia dalam 100 $\mathrm{ml}$ limbah cair tahu adalah air sebanyak 4,9 gram, protein 17,4 gram, mineral 4,3 gram, kalsium 19 miligram, phospor 29 miligram, dan zat besi 4 miligram. Limbah cair tahu juga mengandung karbohidrat, protein, lemak, besi, fosfor, air, serta nitrogen dan kalium yang sangat dibutuhkan oleh tanaman.

\subsection{Diameter Batang.}

Diameter batang merupakan salah satu paramemeter yang dapat di ukur untuk mengetahui pertumbuhan tanaman. Data diameter batang hasil penelitian dapat dilihat pada Gambar 2.

Data pada Gambar 2 menunjukkan bahwa diameter rumput gajah yang diberi perlakuan frekuensi penyiraman limbah tahu 2 hari sekali $\left(R_{2}\right)$ menghasilkan diameter batang terbaik sebesar $0,58 \mathrm{~cm} /$ tanaman, diikuti perlakuan frekuensi penyiraman 6 hari sekali $\left(R_{3}\right)$ dengan diameter batang 0,56 $\mathrm{cm} /$ tanaman, frekuensi penyiraman 4 hari sekali $\left(\mathrm{R}_{1}\right)$ dengan diameter batang $0,54 \mathrm{~cm} /$ tanaman, sedangkan yang terendah adalah pada tanaman dengan perlakuan kontrol (tanpa penyiraman limbah tahu) dengan diameter batang 0,44 $\mathrm{cm} /$ tanaman.
Hasil analisis sidik ragam menunjukkan bahwa penggunaan limbah tahu cair dengan frekuensi waktu penyiraman berbeda berpengaruh nyata $(\mathrm{P}<0,05)$ terhadap pertumbuhan diameter batang rumput gajah. Hasil ini menunjukkan bahwa tanaman rumput gajah memberikan respon pertumbuhan dalam hal ini diameter batang yang optimal dengan frekuensi waktu penyiraman limbah tahu cair. Pertambahan diameter batang terendah adalah pada perlakuan $R_{0}=0,44$ dan tertinggi adalah $R_{2}=0,58$. Hal ini disebabkan karena unsur hara yang disediakan dari perlakuan tersebut dapat memenuhi kebutuhan pertambahan diameter batang rumput gajah, sehingga untuk meningkatkan diameter batang pada rumput gajah. Perlakuan frekuensi waktu penyiraman harus memiliki batas optimal, yang mana dalam penelitian ini perlakuan $R_{2}(0,58 \mathrm{~cm})$ frekuensi waktu yang optimal dalam penyiraman limbah tahu cair. Pertambahan diameter batang tanaman juga menunjukkan jelas adanya pengaruh dari peran kandungan unsur hara $\mathrm{N}, \mathrm{P}, \mathrm{K}$ dan hara mikro yang terkandung dalam limbah tahu cair. Hal tersebut sesuai pendapat Georgiadis (2007) bahwa energi yang dihasilkan dari proses fisiologis dalam tanaman dengan memanfaatkan unsure nitrogen dari dalam tanah, digunakan untuk pertumbuhan tanaman, diantaranya pada segi ukuran diameter batang.

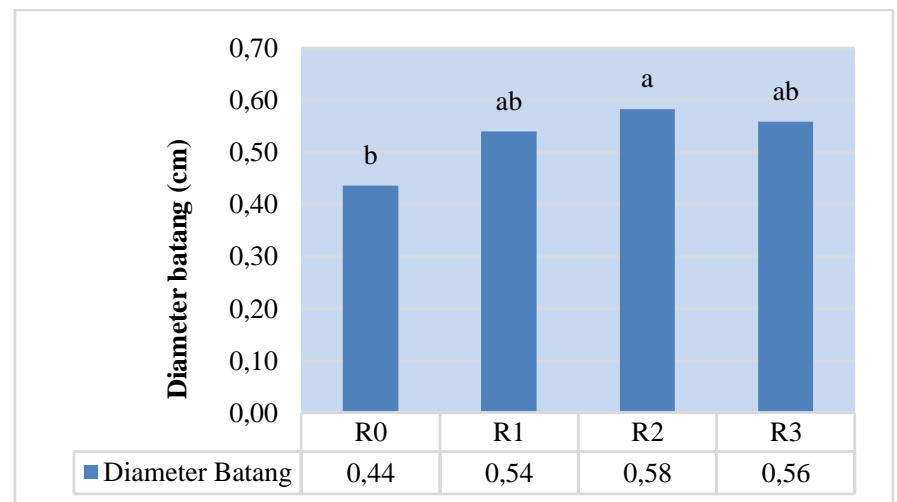

Gambar 2. Rataan Pertumbuhan Diameter Batang (cm/tanaman); Huruf yang sama pada gambar diatas menunjukkan tidak berbeda nyata pada $\alpha 0,05$.

\subsection{Berat Segar Daun (BSD)}

Berat segar merupakan salah satu parameter dalam pertumbuhan suatu tanaman dan juga berperan dalam menentukan kualitas hasil atau produksi, yang diambil datanya setelah panen yang disabit disetiap rumpunnya atau tanaman. Data berat segar daun rumput gajah yang diambil pada waktu saat panen yang lebih jelasnya dapat dilihat pada Gambar 3

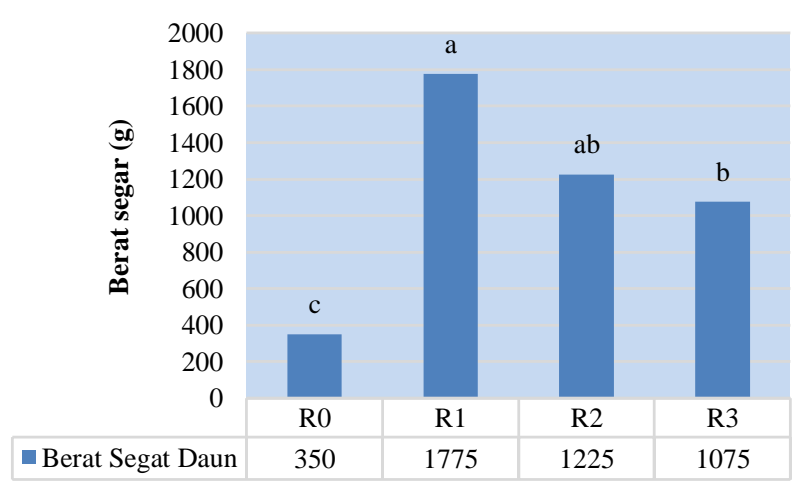

Gambar 3. Rataan Berat Segar Daun (g/tanaman); Huruf yang berbeda pada gambar diatas menunjukkan berbeda nyata pada $\alpha 0,05$.

Data pada Gambar 3 menunjukkan bahwa berat segar daun rumput gajah yang diberi perlakuan frekuensi penyiraman limbah tahu 2 hari sekali $\left(R_{1}\right)$ menghasilkan berat segar terbaik sebesar $1775 \mathrm{~g}$, diikuti perlakuan frekuensi penyiraman 6 hari sekali $\left(\mathrm{R}_{2}\right)$ dengan berat segar $1225 \mathrm{~g}$, Frekuensi penyiraman 4 hari sekali $\left(\mathrm{R}_{3}\right)$ dengan berat segar $1075 \mathrm{~g}$, sedangkan yang terendah adalah pada tanaman dengan perlakuan kontrol (tanpa penyiraman limbah tahu) dengan berat segar $350 \mathrm{~g}$. Hasil analisis sidik ragam (anova) menunjukan bahwa pemberian perlakuan frekuensi penyiraman limbah tahu cair memberikan pengaruh nyata $(\mathrm{P}<0,05)$ terhadap berat segar daun rumput gajah yang dihasilkan.

Hasil uji jarak berganda Duncan memperlihatkan bahwa antara semua pasangan perlakuan menunjukkan perbedaan nyata terhadap berat segar daun yang dihasilkan dalam artian bahwa tiap perlakuan frekuensi penyiraman limbah tahu cair yang diberikan akan menghasilkan karakter yang berbeda terhadap berat segardaun yang dihasilkan. Tingginya produksi berat segar daun yang dihasilkan pada perlakuan R1 disebabkan karena dengan frekuensi penyiraman limbah tahu cair tiap 2 hari sekali mampu menyediakan hara bagi produksi berat segar rumput gajah yang dihasilkan dibandingkan pada perlakuan $R_{2}, R_{3}$ maupun tanaman kontrol $\left(\mathrm{R}_{0}\right)$. Sumber hara pada limbah tahu cair berupa $\mathrm{N} ; 2,11 \% \mathrm{P}$; 
$1,30 \%$ dan $\mathrm{K} 1,80 \%$ yang tersedia pada tanah, digunakan secara maksimal sebagai bahan organik yang dipakai untuk pertumbuhan tanaman (Asmoro 2008).

\subsection{Berat Kering Daun (BKD)}

Hasil pengukuran produksi berat kering daun pada rumput gajah yang diberi perlakuan frekuensi waktu penyiraman limbah tahu cair dapat diliat pada Gambar 4.

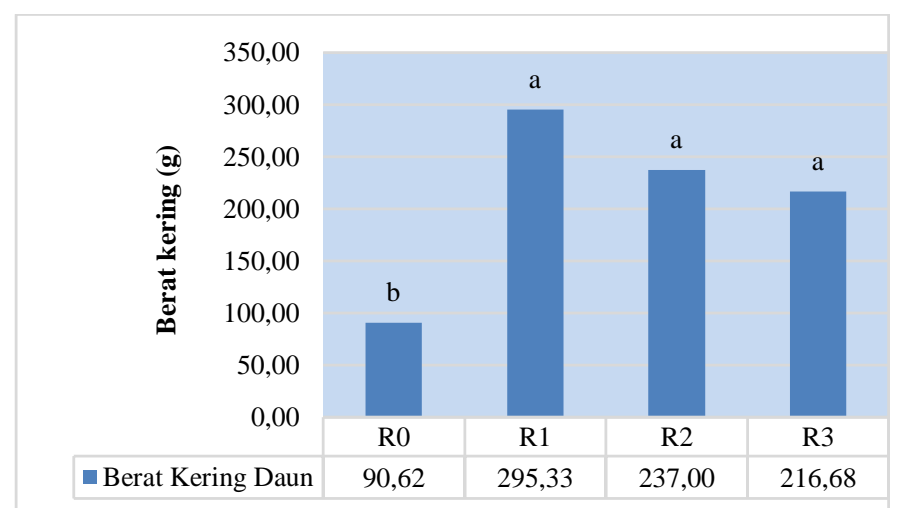

Gambar 4. Rataan Berat Kering Daun (g/tanaman); Huruf yang berbeda pada gambar diatas menunjukkan tidak berbeda nyata pada $\alpha 0,05$.

Hasil pada Gambar 4 menunjukkan bahwa ratan tertinggi terdapat perlakuan $\mathrm{R}_{1} .(295,33)$ diikuti $\mathrm{R}_{2}(237,00), \mathrm{R}_{3}(216,68)$ dan yang terendah adalah $\mathrm{R}_{0}(90,62)$ tanpa perlakuan. Hal ini menunjukkan bahwa pemberian perlakuan limbah tahu cair dengan frekuensi waktu penyiraman terhadap berat kering daun rumput gajah memberikan pengaruh positif.

Hasil analisis sidik ragam (anova) menunjukkan bahwa pemberian perlakuan frekuensi penyiraman limbah tahu cair tidak berpengaruh nyata $(\mathrm{P}>0,05)$ terhadap berat kering daun rumput gajah yang dihasilkan. Hasil penelitian menujukan bahwa berat kering daun pada tanaman rumput gajah yang diberi perlakuan penyiraman limbah tahu cair dengan metode frekuensi waktu penyiraman berbeda secara statistik menunjukkan produksi berat kering daun yang sama. Hal ini karna limbah tahu cair sebagai pupuk cair bagi tanaman memberikan sumbangan yang tinggi terhadap kesuburan tanah sehinga memberikan pengaruh yang sama terhadap produksi berat kering yang dihasilkan. Hal ini sesuai sesuai pendapat Indahwati (2008) dalam Saenab et al (2018) bahwa limbah tahu cair dari hasil analisis mengandung zat-zat karbohidrat, protein, lemak dan mengandung unsur hara yaitu $\mathrm{N}, \mathrm{P}, \mathrm{K}, \mathrm{Ca}, \mathrm{Mg}$. Hal ini membuktikan bahwa limbah cair tahu dapat dijadikan pupuk sebab didalam limbah cair tahu tersebut memiliki ketersediaan nutrisi yang dibutuhkan oleh tanaman.

\section{Simpulan}

Disimpulkan bahwa pemberian perlakuan limbah tahu cair berpengaruh nyata terhadap berat segar daun yang dihasilkan namun tidak berbeda pada tinggi tanaman, diameter batang, dan berat kering daun yang dihasilkan. Secara umum tanaman rumput gajah yang diberi perlakuan penyiraman limbah tahu cair tiap 2 hari sekali menghasilkan nilai tinggi tanaman, diameter batang, berat segar daun dan berat kering daun yang lebih baik dibandingkan perlakuan lainnya.

\section{Pustaka}

Asmoro, Y. 2008. Pemanfaatan limbah tahu untuk peningkatan hasil tanaman petsai (Brassica chinensis). Jurnal Bioteknologi, 5 (2) : 51-55.

Bahri, S. 2006. Pemanfaatan Tumbuhan Air (Azzola) untuk Pengolahan Limbah Cair Industri Tahu di Desa Bandarjaya Kecamatan Terbanggi Besar Lampung Tengah, Fakultas Matematika dan Ilmu Pengetahuan Alam, Universitas Lampung, Lampung.

Fahmi, A., Syamsudin., S. N. H. Utami dan B. Radjagukguk. 2010. Pengaruh Interaksi Hara Nitrogen dan Fosfor Terhadappertumbuhan Tanaman Jagung (Zea Mays L) Pada Tanah Regosol dan Latosol. Berita Biologi, 10(3) : 297-304.

Farida, Ali. 2009. Pembuatan Kompos Dari Ampas Tahu Dengan Activator Stardec. Jurusan Teknik Kimia, Fakultas Teknik Universitas Sriwijaya. Palembang.

Georgiadis, N. J, 2007. Savana Herbivore Dynamics In ALivestock-Dominated Landscape. II:Ecological, Conservation, And Management Implication Of Predator Restoration. Journal of Biological Conservation, 137 (3):207212.

Saenab S, M H I A Muhdar, F Rohman, A N Arifin. 2018. Pemanfaatan Limbah Cair Industri Tahu Sebagai Pupuk Organik Cair (POC) Guna Mendukung Program Lorong Garden (Longgar) Kota Makassar Prosiding Seminar Nasional Megabiodiversitas Indonesia ISBN: 978-602-72245-3-7

Sanderson, M. A and R. A., Paul. 2008. Perennial Forages assecond generation bioenergy crops. International Journal of Molecular Sciences, 9.768-788.
Suyitman, S. Jalaludin, Abudinar, N. Muis, Ifradi, N. Jamaran, M. Peto, dan Tanamasni. 2003. Agrostologi. Fakultas Peternakan Universitas Andalas, Padang.

Winarni, E., R.D. Ratnani dan I. Riwayati. 2013. Pengaruh Jenis Pupuk Organik Terhadap Pertumbuhan Tanaman Kopi. Momentum, 9 (1) : 35-39.

Yudhistira, B., M. Andriana dan R. Utami. 2016. Karakterisasi: Limbah Cair Industri Tahu Dengan Koagulan Yang Berbeda (Asam Asetat dan Kalsium Sulfat). Caraka Tani-Journal of Sustainable Agriculture, 31(2):137-145. 